\title{
PENYELESAIAN SENGKETA ANTARA PEKERJA DAN PERUSAHAAN TENTANG HAK ATAS INFORMASI ${ }^{*}$
}

\author{
Izza Hasna Fuada \\ Program Magister Kenotariatan, Universitas Andalas, \\ J1. Pancasila No. 10 Padang, Sumatera Barat \\ izzahasnafuada@yahoo.com
}

\begin{abstract}
The Disputes between employees of PT. Pos Indonesia (Persero) and PT. Pos Indonesia (Persero) Regional II Padang were happened by the failure of workers in the selection to be Head of Subdivision Post Office, in particular with the medical test. The dispute unfortunately was also escalated by the request for information disclosure which is not granted by the committee. The study aims to is address on the question on how to resolve disputes between workers and companies about the right to information on the final recruitment's selection of employees in particular with PT. Pos Indonesia (Persero) Intake Program Diploma III (D-III) for head of subdivision in the post office. Aside of that, the author also would like to know whether the legal consequences of the central information commission's decision number: 1356/KIP-PS-A-M/2014 in resolving disputes between workers and companies on the right to information. By using the empirical juridical methods, the result shows that the dispute between workers and PT. Pos Indonesia (Persero) companies Regional II Padang can be settled by the Central Information Commission on Mediation and public information is a right for public as also regulated in Law No. 14 of 2008 concerning Public Information Openness
\end{abstract}

Keywords: Dispute Resolution; Workers; Companies; Right to Information.

\begin{abstract}
Abstrak
Sengketa antara pekerja yang merupakan karyawan PT. Pos Indonesia (Persero) dengan Perusahaan PT. Pos Indonesia (Persero) Regional II Padang disebabkan oleh ketidaklulusan pekerja dalam Tes Penerimaan Karyawan PT. Pos Indonesia (Persero) Intake Program Diploma III (D-III) untuk calon Kepala Kantor Pos Cabang Nomor: SK.2966/DIR.SDM/1014. Sengketa terjadi karena tidak ditanggapinya permintaan informasi atas ketidaklulusan pekerja pada Tes Penerimaan Karyawan PT. Pos Indonesia (Persero) Intake Program Diploma III (D-III) untuk Calon Kepala Kantor Pos Cabang. Berdasarkan hal diatas maka penelitian ini akan bertujuan untuk mengetahui bagaimana penyelesaian sengketa antara pekerja dan perusahaan tentang hak atas informasi hasil seleksi akhir rekrutmen karyawan PT. Pos Indonesia (Persero) Intake Program Diploma III (D-III) untuk Calon Kepala Kantor Pos Cabang Nomor: SK.2966/DIR.SDM/1014, untuk mengetahui apakah akibat hukum putusan Mediasi Komisi Informasi Pusat Nomor: 1356/KIP-PS-A-M/2014 dalam penyelesaian sengketa antara pekerja dan perusahaan tentang hak atas informasi hasil seleksi akhir rekrutmen karyawan PT. Pos Indonesia (Persero) Intake Program Diploma III (D-III) untuk calon Kepala Kantor Pos Cabang Nomor: SK.2966/DIR.SDM/1014, dan untuk mengetahui apa kendala pekerja untuk menindak lanjuti hak yang diperoleh setelah putusan Komisi Informasi Pusat Nomor :1356/KIP-PS-A-M/2014 di dalam KD 37/DIRUT/0614 tentang Penerimaan karyawan PT. Pos Indonesia (Persero) Intake Program Diploma III (D-III) untuk calon Kepala Kantor Pos Cabang. Mencari jawaban atas permasalahan tersebut penulis melakukan penelitian dengan metode Yuridis Empiris. Hasil penelitian menunjukkan bahwa sengketa antara pekerja dan perusahaan PT. Pos Indonesia (Persero) Regional II Padang diselesaikan dengan Komisi Informasi Pusat secara mediasi karena informasi tentang ketidak lulusan pekerja dalam Tes Penerimaan Karyawan PT. Pos Indonesia (Persero) Intake Program Diploma III (D-III) untuk calon Kepala
\end{abstract}

\footnotetext{
* Naskah diterima: 4 Januari 2020, direvisi: 3 Maret 2020, disetujui untuk terbit: 26 Maret 2019

Doi: $10.3376 /$ jch.v5i2.213
} 
Kantor Pos Cabang merupakan bagian dari suatu informasi publik sebagaimana diatur di dalam Undang-Undang RI No. 14 Tahun 2008 tentang Keterbukaan Informasi Publik.

Keywords: Penyelesaian Sengketa; Pekerja; Perusahaan; Hak Atas Informasi.

\section{PENDAHULUAN}

Di era globalisasi ini, informasi merupakan kebutuhan pokok setiap orang bagi perkembangan pribadi dan lingkungan sosialnya baik di bidang Politik, Hukum, dan Budaya. Melalui globalisasi serta keterbukaan teknologi informasi maka kegiatan di segala bidang menjadi bersifat terbuka sehingga mengakibatkan komunikasi dan informasi dapat diakses dan dilakukan dimana saja dan kapan saja.(Penjelasan UU RI No.14 Tahun 2008 tentang Keterbukaan Informasi Publik).

Khususnya di Indonesia sebagai negara yang sedang berkembang, menuntut adanya kebebasan informasi bagi setiap warga negaranya baik di bidang ilmu pengetahuan, teknologi maupun di dalam sistem pemerintahan. Kebebasan informasi merupakan suatu sarana penting yang menjadi kebutuhan untuk konsumsi publik, masyarakat yang butuh akan informasi dapat mengakses berbagai informasi yang dibutuhkannya melalui berbagai macam media baik media elektronik maupun media lainnya. (Penjelasan UU RI No.14 Tahun 2008 tentang Keterbukaan Informasi Publik).

Sejalan dengan perkembangan tersebut, maka bentuk-bentuk informasi terus berkembang cepat mengikuti perkembangan ilmu dan teknologi. Perubahan dan perkembangan tersebut terjadi karena kebutuhan informasi yang dikehendaki oleh sebagian besar masyarakat, yang dapat membantu memberikan informasi yang jelas, tepat dan akurat. (Penjelasan UU RI No.14 Tahun 2008 tentang Keterbukaan Informasi Publik).

Kebebasan memperoleh informasi adalah hak setiap orang yang wajib dihormati. Oleh karena itu kebebasan memperoleh informasi merupakan bagian dari hak asasi manusia. Kebebasan dalam memperoleh informasi bagi setiap orang sebagai warga negara Indonesia terdapat dalam UU RI No. 14 Tahun 2008 tentang Keterbukaan Informasi Publik sebagaimana ditegaskan pula dalam UUD RI Tahun 1945 Pasal 28 F disebutkan bahwa:

"Setiap orang berhak untuk berkomunikasi dan memperoleh informasi untuk mengembangkan pribadi dan lingkungan sosialnya, serta berhak untuk mencari, memperoleh, memiliki, dan menyimpan informasi dengan menggunakan segala jenis saluran yang tersedia."

Dalam perjalanannya, seiring dengan era kebebasan informasi, anggota masyarakat yang sedang membangun tidak akan dapat mencegah akibat-akibat berbagai kegiatannya yang akan bergesekan satu dengan yang lainnya. Di dalam pergesekan tersebut, tidak dapat terelakkan terjadinya pertentanganpertentangan yang akhirnya akan menjelma sebagai suatu sengketa yang 
Izza Hasna Fuada: Penyelesaian Sengketa Antara Pekerja Dan Perusahaan Tentang Hak...

dapat terjadi setiap saat. Keadaan pertentangan tersebut sekilas tampak tidak berarti dan kecil, sehingga mungkin saja terabaikan, tetapi tiba-tiba muncul tanpa diperhitungkan sebelumnya (Frans Hendra, 2012: 1).

Sengketa atau perselisihan atau dalam bahasa inggris disebut dengan conflict atau dispute merupakan suatu akibat yang terjadi dari hubungan antar manusia sebagai makhluk sosial yang selalu berinteraksi dengan manusia lain. Sengketa dalam hukum ketenagakerjaan biasa disebut dengan perselisihan hubungan industrial. Sebagaimana diatur di dalam UU RI No. 13 Tahun 2003 Tentang Ketenagakerjaan Pasal 1 angka 22 menyebutkan bahwa:

"Perbedaan pendapat yang mengakibatkan pertentangan antara pengusaha atau gabungan pengusaha dengan pekerja/buruh atau serikat pekerja/serikat buruh karena adanya perselisihan mengenai hak, perselisihan kepentingan, dan perselisihan pemutusan hubungan kerja serta perselisihan antar serikat pekerja/serikat buruh hanya dalam satu perusahaan."

Sesuai dengan judul diatas yaitu Penyelesaian Sengketa Antara Pekerja dengan Perusahaan, yang dimaksud dengan perusahaan di sini adalah PT. Pos Indonesia (Persero) Regional II Padang yang dalam Peraturan Komisi Informasi Nomor 1 Tahun 2010 tentang Standar Layanan Informasi Publik termasuk Badan Publik sebagaimana diatur dalam pasal 1 angka 3 menyebutkan:

"Badan Publik adalah lembaga eksekutif, legislatif, yudikatif, dan badan lain yang fungsi dan tugas pokoknya berkaitan dengan penyelenggaraan negara, yang sebagian atau seluruh dananya bersumber dari anggaran pendapatan dan belanja negara dan/atau anggaran pendapatan dan belanja daerah, atau organisasi non pemerintah sepanjang sebagian atau seluruh dananya bersumber dari anggaran pendapatan dan belanja negara dan/atau anggaran pendapatan dan belanja daerah, sumbangan masyarakat, dan atau luar negeri."

PT. Pos Indonesia (Persero) merupakan Badan Usaha Milik Negara (BUMN), yang mana karyawan BUMN berdasarkan Pasal 87 angka 1 UU RI No. 19 Tahun 2003 tentang BUMN menyebutkan:

"Karyawan BUMN merupakan pengangkatannya, pemberhentian, kedudukan, hak dan kewajibannya ditetapkan berdasarkan perjanjian kerja bersama sesuai dengan ketentuan Peraturan perundangundangan di bidang ketenagakerjaan"

Salah satu pekerja yang merupakan karyawan PT. Pos Indonesia (Persero) mengikuti Tes Penerimaan Karyawan PT. Pos Indonesia (Persero) Intake Program Diploma III (D-III) untuk Calon Kepala Kantor Pos Cabang Nomor: KD.37/DIRUT/0614. Berdasarkan Surat Keputusan Direksi PT. Pos Indonesia (Persero)

Nomor:

SK.2996/DIR.SDM/1014 tentang Hasil Seleksi Akhir Penerimaan Karyawan PT. Pos Indonesia (Persero) Intake Program Diploma III (D-III) untuk Calon Kepala 
Kantor Pos Cabang, Pekerja dinyatakan "Tidak Lulus".

Sehubungan dengan perihal hasil seleksi akhir rekrutmen karyawan PT. Pos Indonesia (Persero) Intake Program Diploma III (D-III) untuk Calon Kepala Kantor Pos Cabang, pekerja yang bersangkutan meminta kejelasan secara transparan dari PT. Pos Indonesia (Persero) Regional II Padang tentang tidak lulusnya pekerja. Dalam hal ini pekerja yang bersangkutan merasakan adanya ketidak transparan dalam proses penetapan keputusan tersebut.

Kejelasan atas tidak lulusnya pekerja pada seleksi Tes Penerimaan karyawan PT. Pos Indonesia (Persero) Intake Program Diploma III (D-III) untuk Calon Kepala Kantor Pos Cabang bukan merupakan hak sebagaimana yang diatur dalam UU RI No. 13 Tahun 2003 tentang Ketenagakerjaan, tetapi kejelasan tersebut berbentuk keterangan, pernyataan yang mengandung nilai dan makna.

Keterangan, pernyataan yang mengandung nilai dan makna disebut dengan Informasi. Menurut Pasal 1 angka 1 UU RI No. 14 Tahun 2008 tentang Keterbukaan Informasi Publik menyatakan bahwa:

"Informasi adalah keterangan, pernyataan, gagasan, dan tanda-tanda yang mengandung nilai, makna, dan pesan, baik data, fakta maupun penjelasannya yang dapat dilihat, didengar, dan dibaca yang disajikan dalam berbagai kemasan dan format sesuai dengan perkembangan teknologi informasi dan komunikasi secara elektronik ataupun nonelektronik."

Informasi yang dimohonkan oleh pekerja kepada perusahaan merupakan Informasi Publik, yang diatur dalam pasal 1 angka 2 UU RI No. 14 Tahun 2008 tentang Keterbukaan Informasi Publik yang menyebutkan:

"Informasi publik adalah informasi yang dihasilkan, disimpan, dikelola, dikirim, dan/atau diterima oleh suatu badan publik yang berkaitan dengan penyelenggara dan penyelenggaraan negara dan/atau penyelenggara dan penyelenggaraan badan publik lainnya yang sesuai dengan undangundang ini serta informasi lain yang berkaitan dengan kepentingan publik."

Pekerja merupakan orang yang bekerja di perusahaan PT. Pos Indonesia (Persero), yang mana dalam UU RI No. 14 Tahun 2008 tentang Keterbukaan Informasi Publik setiap orang mempunyai hak atas informasi yang secara tegas diatur Pasal 4 UU RI No. 14 Tahun 2008 Tentang Keterbukaan Informasi Publik, yang menyebutkan:

(1) Setiap orang berhak memperoleh informasi publik sesuai dengan ketentuan undang-undang ini

(2) Setiap orang berhak:

a. Melihat dan mengetahui informasi publik

b. Menghadiri pertemuan publik yang terbuka untuk umum untuk memperoleh informasi publik

c. Mendapatkan salinan informasi publik melalui permohonan sesuai dengan undang-undang ini dan/atau

d. Menyebarluaskan informasi publik sesuai dengan 
Izza Hasna Fuada: Penyelesaian Sengketa Antara Pekerja Dan Perusahaan Tentang Hak...

peraturan perudang-undangan

(3) Setiap pemohon informasi publik mengajukan permintaan informasi publik disertai alasan permintaan tersebut

(4) Setiap pemohon informasi publik berhak mengajukan gugatan ke pengadilan apabila dalam memperoleh informasi publik mendapat hambatan atau kegagalan sesuai dengan ketentuan undang-undang ini.

Sehingga kejelasan atas tidak lulusnya pekerja pada seleksi Tes Penerimaan karyawan PT. Pos Indonesia (Persero) Intake Program Diploma III (DIII) untuk Calon Kepala Kantor Pos Cabang merupakan bagian dari suatu Informasi Publik, sebagaimana diatur dalam Peraturan Komisi Informasi Nomor 1 Tahun 2010 tentang Standar Layanan Informasi Publik Bab III yaitu Informasi yang wajib disediakan dan diumumkan sebagaimana ditentukan dalam pasal 11 ayat (1) huruf b ringkasan informasi tentang program dan/atau kegiatan yang sedang dijalankan dalam lingkup Badan Publik, angka 8 yaitu:

"Informasi tentang penerimaan calon pegawai dan/atau pejabat badan publik negara".

Oleh karena itu terjadilah yang namanya sengketa, sengketa adalah suatu situasi dimana ada pihak yang merasa dirugikan dalam hal ini pekerja yang merupakan karyawan PT. Pos Indonesia (Persero), oleh Perusahaan PT. Pos Indonesia (Persero) Regional II Padang.

Sengketa yang terjadi adalah pekerja yang bersangkutan tidak mendapatkan haknya berupa informasi sebagaimana yang dimaksud pasal 1 angka 1 UU RI No. 14 Tahun 2008 Tentang Keterbukaan Informasi Publik yaitu kejelasan secara transparan tentang ketidak lulusnya pekerja dalam tes penerimaan karyawan PT. Pos Indonesia (Persero) Intake Program Diploma III (D-III) untuk Calon Kepala Kantor Pos Cabang.

Untuk mendapatkan hak atas informasi tersebut pekerja yang bersangkutan mengajukan permohonan ke Komisi Informasi Pusat. Keberadaan Komisi Informasi Pusat diatur dalam UU RI No. 14 Tahun 2008 tentang Keterbukaan Informasi Publik. Komisi Informasi Pusat yang selanjutnya disebut dengan Komisi Informasi adalah lembaga mandiri yang berfungsi menjalankan undang-undang ini dan peraturan pelaksananya, menetapkan petunjuk teknis standar layanan informasi publik melalui mediasi dan/atau ajudikasi nonlitigasi. (Dyah Aryani, 2015: 3)

Secara komprehensif UU RI No. 14 Tahun 2008 tentang Keterbukaan Informasi Publik mengatur mengenai kewajiban badan publik negara untuk memberikan pelayanan informasi terbuka, transparan, dan bertanggung jawab kepada masyarakat khususnya pekerja yang bersangkutan yang merupakan bagian dari masyarakat dan juga merupakan bagian dari pengguna informasi publik. (Dyah Aryani, 2015)

Undang-Undang Keterbukaan Informasi Publik memberikan jaminan kepada setiap warga negara untuk memperoleh informasi yang dimiliki oleh badan publik. (Dyah Aryani, 2015: 1). 
Undang-Undang Keterbukaan Informasi Publik berisi acuan yang jelas tentang tata cara memperoleh informasi dari badan publik, hak dan kewajiban badan publik, serta tata cara penyelesaian sengketa ketika hak pekerja sebagai pemohon informasi publik untuk memperoleh informasi terhambat atau dihambat oleh pejabat di dalam badan publik khususnya Perusahaan PT. Pos Indonesia (Persero) Regional II Padang. Jika dalam melakukan akses dan permintaan informasi, pekerja yang bersangkutan mendapat kesulitan dan hambatanhambatan, badan publik yaitu Perusahaan PT. Pos Indonesia Regional II Padang tidak memberikan informasi yang diminta, serta pekerja merasa tidak puas atas perlakuan tersebut, maka dapat dikatakan bahwa telah terjadi Sengketa Informasi Publik. (Trie Ayu Sudarti, 2014: 2)

Menurut UU RI No. 14 Tahun 2008 tentang Keterbukaan Informasi Publik Pasal 1 angka 5, disebutkan bahwa:

"Sengketa Informasi Publik adalah
sengketa yang terjadi antara badan
publik dan pengguna informasi
publik yang berkaitan dengan hak
memperoleh dan menggunakan
informasi berdasarkan perundang-
undangan" Jika terjadi sengketa informasi publik, maka pemohon informasi publik yaitu pekerja dapat menempuh mekanisme penyelesaian sengketa yang diatur dalam UU RI No. 14 Tahun 2008 tentang Keterbukaan Informasi Publik.

Berdasarkan uraian diatas, maka penulis tertarik untuk mengangkat fenomena hukum mengenai hak atas informasi dalam upaya penegakan hukum terhadap penyelesaian sengketa antara pekerja dan perusahaan yang semakin hari semakin banyak dan untuk memberikan solusi terbaik bagi para pihak yang bersengketa.

Dengan rumusan masalah sebagai berikut: Bagaimana penyelesaian sengketa antara pekerja dan perusahaan tentang hak atas informasi hasil seleksi reksrutmen karyawan PT. Pos Indonesia (Pesero) Intake Program D-III untuk calon Kepala Kantor Pos Cabang Nomor: SK.2966/DIR/1014 ? Apa akibat hukum putusan Komisi Informasi Pusat: 1356/KIP-PS-A-M/2014 dalam penyelesaian sengketa antara pekerja dan perusahaan tentang hak atas informasi hasil seleksi akhir rekrutmen karyawan PT. Pos Indonesia (Persero) Intake Program D-III untuk calon kepala kantor pos cabang Nomor: SK.2966/DIR.SDM.1014 ? Apa kendala pekerja menindak lanjuti hak yang diperoleh setelah putusan Komisi Informasi Pusat Nomor: 1356/KIP-PS-AM/2014 dalam KD. 37/DIRUT/0614 tentang penerimaan karyawan PT. Pos Indonesia (Persero) Intake Program D-III untuk calon Kepala Kantor Pos Cabang ?

\section{METODE PENELITIAN}

Metode Pendekatan masalah yang akan dipergunakan dalam penelitian ini adalah pendekatan Yuridis Empiris. Pendekatan Yuridis Empiris yaitu mengkaji ketentuan hukum yang berlaku serta apa yang terjadi dalam kenyataan masyarakat, (Suharsimi Arikunto, 2002: 
Izza Hasna Fuada: Penyelesaian Sengketa Antara Pekerja Dan Perusahaan Tentang Hak...

126) atau dengan kata lain yaitu suatu penelitian yang dilakukan terhadap keadaan sebenarnya atau keadaan nyata yang terjadi di masyarakat dengan maksud untuk mengetahui dan menemukan fakta-fakta dan data yang dibutuhkan, setelah data yang dibutuhkan terkumpul kemudian menuju kepada identifikasi masalah yang pada akhirnya menuju pada penyelesaian masalah. (Bambang Waluyo: 17)

\section{HASIL DAN PEMBAHASAN}

1. Penyelesaian Sengketa antara Pekerja dan Perusahaan tentang Hak Atas Informasi Hasil Seleksi Akhir Rekrutmen Karyawan PT. Pos Indonesia (Persero) Intake Program Diploma III (D-III) untuk Kepala Kantor Pos Cabang Nomor: SK.2966/DIR.SDM/1014

Sengketa antara pekerja yang merupakan karyawan PT. Pos Indonesia (persero) dengan Perusahaan PT. Pos Indonesia (Persero) Regional II Padang pada Seleksi Tes Penerimaan Karyawan PT. Pos Indonesia (Persero) Intake Program Diploma III (D-III) untuk Calon Kepala Kantor Pos Cabang merupakan bagian dari suatu Informasi Publik.

Informasi Publik yang dimohonkan oleh Pemohon Informasi Publik adalah informasi yang dihasilkan, disimpan, dikelola, dikirim, dan/atau diterima oleh suatu Badan Publik yang berkaitan dengan penyelenggara dan penyelenggaraan negara dan/atau penyelenggara dan penyelenggaraan Badan Publik lainnya yang sesuai dengan undang-undang keterbukaan informasi publik serta informasi lain yang berkaitan dengan kepentingan publik. (Komisi Informasi Pusat: 1)

Informasi terdiri dari informasi yang wajib disediakan dan diumumkan secara berkala, informasi yang wajib diumumkan secara serta merta, informasi yang wajib tersedia setiap saat dan informasi yang dikecualikan. (UU KIP)

Informasi Publik dalam sengketa pekerja dengan perusahaan PT. Pos Indonesia (Persero) Regional II Padang yaitu sebagaimana diatur dalam Peraturan Komisi Informasi Nomor 1 Tahun 2010 tentang Standar Layanan Informasi Publik Bab III yaitu Informasi yang wajib disediakan dan diumumkan sebagaimana ditentukan dalam Pasal 11 ayat (1) huruf b ringkasan informasi tentang program dan/atau kegiatan yang sedang dijalankan dalam lingkup Badan Publik, angka 8 yaitu:

"Informasi tentang penerimaan calon pegawai dan/atau pejabat badan publik negara".

Sehingga dapat dikatakan bahwa sengketa antara pekerja dan perusahaan PT. Pos Indonesia (Persero) Regional II Padang merupakan Sengketa Informasi Publik. Sengketa Informasi Publik adalah sengketa yang terjadi antara Badan Publik dan Pengguna Informasi Publik yang berkaitan dengan hak memperoleh dan menggunakan informasi berdasarkan perundang-undangan. (Komisi Informasi Pusat: 4)

Sebagaimana yang disebutkan dalam UU RI No. 14 Tahun 2008 tentang Keterbukaan Informasi Publik Pasal 1 angka 3, Badan Publik adalah: 
"Badan Publik adalah lembaga eksekutif, legislatif, yudikatif, dan badan lain yang fungsi dan tugas pokoknya berkaitan dengan penyelenggaraan negara, yang sebagian atau seluruh dananya bersumber dari anggaran pendapatan dan belanja negara dan/atau anggaran pendapatan dan belanja daerah, atau organisasi non pemerintah sepanjang sebagian atau seluruh dananya bersumber dari anggaran pendapatan dan belanja negara dan/atau anggaran pendapatan dan belanja daerah, sumbangan masyarakat, dan/atau luar negeri."

Sedangkan Pemohon Informasi Publik menurut pasal 1 angka 12 UU RI No. 14 Tahun 2008 tentang Keterbukaan Informasi Publik yaitu:

"Pemohon informasi publik adalah warga negara dan/atau badan hukum indonesia yang mengajukan permintaan informasi publik sebagaimana diatur dalam undangundang ini".

Para pihak dalam proses penyelesaian sengketa informasi publik disebut sebagai Pemohon Penyelesaian Sengketa Informasi Publik dan Termohon Penyelesaian Sengketa Informasi Publik. Dalam sengketa antara pekerja dan perusahaan PT. Pos Indonesia (Persero) yang menjadi Pemohon Penyelesaian Sengketa Informasi Publik yang biasanya disebut Pemohon yaitu Pekerja merupakan Karyawan PT. Pos Indonesia (Persero), Pemohon adalah pemohon atau pengguna informasi publik yang mengajukan permohonan kepada Komisi Informasi. Sedangkan Termohon Penyelesaian Sengketa Informasi Publik yang selanjutnya disebut Termohon adalah Perusahaan PT. Pos Indonesia (Persero) Regional II Padang, Termohon adalah Badan Publik yang diwakili oleh Pimpinan Badan Publik yang diberi kewenangan untuk mengambil keputusan dalam penyelesaian sengketa di Komisi Informasi. (Komisi Informasi Pusat : 6)

Sebelum para pihak bertemu dalam proses penyelesaian sengketa informasi publik di Komisi Informasi, Pemohon yaitu pekerja terlebih dahulu melalui suatu tahapan mekanisme memperoleh informasi melalui permohonan informasi kepada Pejabat Pengelola Informasi dan Dokumentasi, Pejabat Pengelola Informasi dan Dokumentasi yaitu Kepala Kantor PT. Pos Indonesia (Persero) Regional II Padang. Setelahnya, Pemohon dapat mengajukan permohonan penyelesaian sengketa informasi publik kepada Komisi Informasi yang sesuai dengan kewenangan realtifnya. (Komisi Informasi Pusat: 6)

Kewenangan Komisi Informasi dalam menyelesaikan permohonan penyelesaian sengketa informasi publik terdiri atas kewenangan absolut dan kewenangan relatif. Kewenangan absolut merupakan kewenangan untuk menyelesaikan sengketa informasi publik, kewenangan relatif merupakan kewenangan penyelesaian sengketa informasi publik yang menyangkut Badan Publik Pusat dan Badan Publik tingkat provinsi dan/atau Badan Publik tingkat Kabupaten/Kota. (Komisi Informasi Pusat: 6)

Dalam permohonan penyelesaian sengketa informasi publik kepada Komisi 
Izza Hasna Fuada: Penyelesaian Sengketa Antara Pekerja Dan Perusahaan Tentang Hak...

Informasi, Pemohon wajib memenuhi syarat formal dan syarat materil. Syarat formal antara lain identitas pemohon yang sah, pemohon informasi kepada badan publik, dan keberatan kepada badan publik.(Komisi Informasi Pusat: 9)

Berdasarkan UU RI No. 14 Tahun 2008 tentang Keterbukaan Informasi Publik Pasal 4 ayat (3) menyatakan bahwa setiap Pemohon Informasi Publik berhak mengajukan permintaan informasi publik disertai alasan permintaan tersebut. (Dyah Aryani, 2015: 8)

Pekerja mengajukan permohonan kepada Komisi Informasi Pusat dengan alasan bahwa pekerja merupakan karyawan PT. Pos Indonesia (Persero) yang mengikuti Tes Penerimaan Karyawan PT. Pos Indonesia (Persero) Intake Program Diploma III (D-III) Untuk Calon Kepala Kantor Pos Cabang berdasarkan KD.37/DIRUT/0614.

Pada seleksi Tahap Tes Kesehatan pekerja dinyatakan tidak lulus dan sudah 3 kali mengirimkan surat kepada Kepala PT. Pos Indonesia (Persero) Regional II Padang untuk meminta informasi kejelasan ketidak lulusan pekerja, Pihak PT. Pos Indonesia (Persero) Regional II Padang tidak merespons atas permintaan informasi tersebut kemudian Pekerja mohon kepada Komisi Informasi Pusat untuk memeriksa bahwa:

1. Informasi yang dimohonkan adalah informasi yang bersifat terbuka sehingga wajib di buka dan diberikan kepada pekerja.
2. Perusahaan PT. Pos Indonesia (Persero) Regional II Padang telah salah karena tidak menanggapi permohonan informasi sebagaimana yang di mohonkan, sehingga perusahaan yang terkait wajib menanggapi permohonan informasi sesuai permohonan.

Dan atas alasan pekerja tersebut mengajukan permohonan penyelesaian sengketa informasi publik di komisi informasi pusat. Pekerja yang bersangkutan mengajukan permohonan penyelesaian sengketa informasi publik kepada komisi informasi pusat sebagai perwujudan hak warga negara indonesia untuk memperoleh informasi dari badan publik dan pekerja mengajukan permohonan penyelesaian sengketa informasi pusat karena berdasarkan pasal 4 angka 1 UU RI No. 14 Tahun 2008 tentang Keterbukaan Informasi Publik menyebutkan:

"Setiap orang berhak memperoleh informasi publik sesuai dengan ketentuan Undang-Undang Ini”

Berdasarkan alasan pekerja tersebut Komisi Informasi Pusat menerima permohonan penyelesaian sengketa informasi publik, dengan dasar yaitu tidak dipenuhinya permohonan informasi yang dimohonkan oleh pekerja (perusahaan tidak memberikan tanggapan/jawaban Pekerja melalui surat sebanyak 3 kali.

Adapun suatu permohonan informasi menjadi sengketa informasi antara pemohon informasi publik dengan badan publik yang kemudian akan menjadi 
termohon, dapat disebabkan oleh beberapa alasan yaitu:

a. Penolakan atas permintaan informasi berdasarkan alasan pengecualian sebagaimana dimaksud dalam pasal 17 UU KIP.

b. Tidak disediakannya informasi berkala sebagaimana dimaksud dalam pasal 9 UU KIP.

c. Tidak ditanggapinya permintaan informasi.

d. Tidak dipenuhinya permintaan informasi.

e. Pengenaan biaya yang tidak wajar dan/atau.

f. Penyampaian informasi yang melebihi waktu yang diatur dalam UU KIP. (Komisi Informasi Pusat : 8)

Setiap informasi publik harus dapat diperoleh setiap pemohon informasi publik dengan cepat dan tepat waktu, biaya ringan, dan cara sederhana. Proses penyelesaian sengketa informasi publik di Komisi Informasi Pusat yang terjadi pada pekerja Karyawan PT. Pos Indonesia (Persero) dengan Perusahaan PT. Pos Indonesia (Persero) Regional II Padang dalam Tes Penerimaan Karyawan PT. Pos Indonesia (Persero) Intake Program Diploma III (D-III) untuk Kepala Kantorpos Cabang berdasarkan Perki 1 Tahun 2013 yaitu dimulai tahapan penerimaan permohonan sengketa dari pemohon pada kepaniteraan Komisi Informasi dan pencatatannya dalam register sengketa informasi yang ditandai dengan penomoran terhadap pemohon penyelesaian sengketa informasi publik. Pencatatan dan pemberian nomor registrasi sengketa juga menandai bahwa sengketa tersebut siap untuk diperiksa sesuai jadwal yang telah ditentukan. (Perki PPSIP 1, 2013)

Permohonan penyelesaian sengketa informasi yang diperiksa dan diputus oleh Majelis Komisioner adalah permohonan yang telah tercatat dalam register sengketa informasi. Dalam sengketa informasi publik yang terjadi pada pekerja Karyawan PT. Pos Indonesia (Persero) dengan Perusahaan PT. Pos Indonesia (Persero) Regional II Padang dalam Tes Penerimaan Karyawan PT. Pos Indonesia (Persero) Intake Program Diploma III (DIII) untuk Kepala Kantorpos Cabang pada hari Jum'at 27 Maret 2015 Komisi Informasi Pusat memanggil Pekerja yang bersangkutan untuk datang menghadiri sidang sengketa informasi publik di kepaniteraan komisi informasi pusat dan hari rabu 8 April 2015 dengan agenda pemeriksaan. (Wawancara dengan Pekerja yang bernama Aqtia Susepti)

Setelah pemeriksaan terhadap sengketa informasi publik dianggap cukup, putusan atas sengketa tersebut akan ditetapkan. Proses penyelesaian sengketa informasi publik selesai dan berakhir dengan dijatuhkannya putusan. Putusan Komisi Informasi Pusat terhadap sengketa informasi publik pekerja Karyawan PT. Pos Indonesia (Persero) dengan Perusahaan PT. Pos Indonesia (Persero) Regional II Padang yaitu pekerja dan perusahaan bersedia untuk menempuh proses penyelesaian sengketa informasi publik melalui 
Izza Hasna Fuada: Penyelesaian Sengketa Antara Pekerja Dan Perusahaan Tentang Hak...

mediasi.(wawancara dengan pekerja yang bernama Aqtia Susepti).

\section{a. Pengertian Mediasi}

Mediasi merupakan penyelesaian sengketa informasi publik antara para pihak melalui bantuan mediator komisi informasi. Mediator adalah komisioner pada Komisi Informasi yang bertugas membantu para pihak dalam proses perundingan guna mencari berbagai kemungkinan penyelesaian sengketa informasi publik tanpa menggunakan cara memutus atau memaksa sebuah penyelesaian.(Buku Saku Mediasi Sengketa Informasi Publik: 2)

\section{b. Pelaksanaan Mediasi}

Mediasi dilakukan jika informasi yang disengketakan bukan informasi yang dikecualikan. Berdasarkan Pasal 40 ayat 2 UU RI No. 14 Tahun 2008 tentang Keterbukaan Informasi Publik bahwa Penyelesaian sengketa melalui mediasi hanya dapat dilakukan terhadap pokok perkara yang terdapat Pasal 35 ayat (1) huruf $b$, huruf $c$, huruf $d$, huruf e, huruf $f$, dan huruf g. (Buku Saku Mediasi Sengketa Informasi Publik: 2)

\section{c. Mediasi Dilakukan}

Mediasi dilakukan pada hari yang sama pada pemeriksaan awal. Apabila para pihak menghendaki lain, mediasi dapat dilakukan pada hari yang disepakati oleh para pihak, selambat-lambatnya 3 (tiga) hari kerja setelah proses ajudikasi dengan materi pemeriksaan awal dilaksanakan dan sidang selanjutnya ditunda. (Buku Saku Mediasi Sengketa Informasi Publik : 6)

\section{d. Sifat Proses Mediasi}

Proses mediasi sengketa pekerja dengan perusahaan PT. Pos Indonesia (Persero) Regional II Padang bersifat tertutup, kecuali para pihak menghendaki lain, yang dimaksud tertutup adalah hanya dihadiri oleh Mediator dan Para Pihak yaitu Pemohon dan Termohon, pihak selain pemohon dan termohon dapat hadir dalam mediasi jika kehadirannya disetujui oleh Pemohon dan Termohon. (Buku Saku Mediasi Sengketa Informasi Publik: 6)

Dalam praktik mediasi sengketa informasi publik, selain pemohon, termohon dan mediator, kehadiran staf komisi informasi dalam proses mediasi dimaksudkan untuk memberi dukungan teknis administrasi selama mediasi berlangsung seperti pencatatan dan penulisan seluruh jalannya proses mediasi dan hasilnya. (Buku Saku Mediasi Sengketa Informasi Publik: 6)

\section{e. Lama Jangka Waktu Mediasi, Tempat Mediasi Dilakukan, Biaya Mediator}

Mediasi antara pekerja dan perusahaan PT. Pos Indonesia (Persero) Regional II Padang dilaksanakan dalam sekali pertemuan, di Kantor Komisi Informasi Provinsi Sumatera Barat serta Para pihak tidak menanggung segala biaya yang dikeluarkan mediator, pelaksanaan mediasi sengketa informasi publik tidak berbiaya dan para pihak tidak dapat secara bebas memilih mediator, mediator ditetapkan oleh Ketua Komisi 
Informasi. (Buku Saku Mediasi Sengketa Informasi Publik: 6)

\section{f. Hasil Mediasi}

Hasil mediasi pekerja dengan Perusahaan PT. Pos Indonesia (Persero) Regional II Padang berupa Kesepakatan Mediasi dalam hal mediasi berhasil. Hasil mediasi pada sengketa informasi publik pekerja yang merupakan Karyawan PT. Pos Indonesia (Persero) dengan Perusahaan PT. Pos Indonesia (Persero) Regional II Padang dalam Tes Penerimaan Karyawan PT. Pos Indonesia (Persero) Intake Program Diploma III (DIII) untuk Kepala Kantorpos Cabang berupa kesepakatan yaitu pemohon (pekerja yang bersangkutan) menerangkan bahwa informasi yang diminta yaitu (Putusan Mediasi KIP No.1356/XI/KIP-PS-A-M/2014):

1. Hasil pemeriksaan kesehatan atas nama pemohon dalm proses seleksi calon kepala kantor pos cabang intake program diploma III (D-III) tahun 2014

2. Penjelasan tertulis dari dokter mengenai hasil pemeriksaan kesehatan atas nama pemohon

3. Rekap hasil pemeriksaan kesehatan atas nama pemohon Sebagaimana informasi yang diminta oleh pekerja yang bersangkutan, termohon yang merupakan Perusahaan PT. Pos Indonesia (Persero) Regional II Padang berdasarkan Putusan Komisi Infroamsi Pusat Putusan Mediasi Nomor $\quad$ 1356/XI/KIP-PS-A-M/2014 sepakat memberikan : a. Hasil pemeriksaan kesehatan atas nama pemohon (pekerja yang bersangkutan) dalam seleksi calon kantor pos cabang intake program diploma III (D-III) tahun 2014.

b. Penjelasan tertulis dari dokter mengenai hasil pemeriksaan kesehatan yang menyebabkan ketidaklulusan dalam seleksi.

c. Salinan rekap hasil pemeriksaan kesehatan dengan menutup datadata yang menyangkut pribadi orang lain.

Pekerja selaku pemohon dan perusahaan selaku termohon bersedia mengakhiri sengketa informasi yang dibuat secara tertulis pada tanggal 8 april 2015 dan menyetujui seluruh kesepakatan tersebut. Putusan komisi informasi yang berasal dari kesepakatan melalui mediasi bersifat final dan mengikat. (Dyah Aryani: 9)

2. Akibat Hukum putusan Mediasi Komisi Informasi Pusat Nomor: 1356/KIP-PS-A-M/2014 dalam Penyelesaian Sengketa antara Pekerja dan Perusahaan tentang Hak atas Informasi Hasil Seleksi Akhir Rekrutmen Karyawan PT. Pos Indonesia (Persero) Intake Program D-III untuk Calon Kepala Kantor Pos Cabang Nomor: SK .2966/DIR.SDM/1014

Komisi Informasi Pusat telah melaksanakan persidangan pada tanggal 8 April 2015 dan dalam persidangan para pihak bersedia menempuh proses penyelesaian sengketa informasi publik melalui mediasi. Mediasi yang dilaksanakan oleh para pihak 
Izza Hasna Fuada: Penyelesaian Sengketa Antara Pekerja Dan Perusahaan Tentang Hak...

menghasilkan kesepakatan-kesepakatan sebagai berikut:

Pemohon menerangkan bahwa informasi yang diminta yaitu:

1. Hasil pemeriksaan kesehatan atas nama pemohon dalam proses seleksi calon Kepala Kantor Pos Cabang Intake Program Diploma III (D-III) tahun 2014.

2. Penjelasan tertulis dari dokter mengenai hasil pemeriksaan kesehatan atas nama pemohon.

3. Rekap hasil pemeriksaan kesehatan atas nama pemohon.

\section{Termohon memberikan penjelasan sebagai berikut:}

1. Bahwa termohon menguasai dan bersedia memberikan hasil pemeriksaan kesehatan atas nama pemohon dalam proses seleksi calon kepala kantor pos cabang intake program Diploma III (D-III) tahun 2014.

2. Bahwa termohon bersedia memberikan penjelasan tertulis dari dokter mengenai hasil pemeriksaan kesehatan atas nama pemohon yang menyebabkan ketidaklulusan pemohon dalam seleksi.

3. Bahwa termohon menguasai dan bersedia untuk memberikan salinan rekap hasil pemeriksaan kesehatan atas nama pemohon dengan menutup data-data yang menyangkut pribadi orang lain.

Para pihak menyepakati untuk melakukan serah terima dokumen dalam bentuk hardcopy paling lama 14 (empat belas) hari kerja setelah kesepakatan mediasi ditandatangani, biaya pengadaan dokumen hard copy dibebankan kepada pihak pekerja. Kesepakatan mediasi, para pihak bersedia mengakhiri sengketa informasi yang dibuat secara tertulis pada tanggal 8 April 2015 dan para pihak menyetujui seluruh kesepakatan tersebut. (Putusan Mediasi KIP No.1356/XI/KIPPS-A-M/2014)

Berdasarkan kesepakatan tersebut Majelis Komisioner menjatuhkan putusan yaitu memerintahkan pemohon (Pekerja) dan termohon (PT. Pos Indonesia (Persero) Regional II Padang) untuk menjalankan kewajiban sebagaimana tertuang dalam kesepakatan.(Putusan Mediasi KIP No.1356/XI/KIP-PS-A$\mathrm{M} / 2014$ )

Permintaan Informasi telah dipenuhi oleh perusahaan PT. Pos Indonesia (Persero) Regional II Padang, berdasarkan Pasal 39 UU No. 14 Tahun 2008 tentang Keterbukaan Informasi Publik menyatakan bahwa:

"Putusan Komisi Informasi yang berasal dari kesepakatan melalui Mediasi bersifat final dan mengikat".

Apabila para pihak atau salah satu pihak tidak melaksanakan putusan tersebut maka berdasarkan UU RI No. 14 Tahun 2008 tentang Keterbukaan Informasi Publik diatur ketentuan pidana pada pasal 52, Pasal 56, dan pasal 57 yang menyatakan bahwa:

Pasal 52:

"Badan Publik yang dengan sengaja tidak menyediakan, tidak memberikan, dan/atau tidak 
menerbitkan informasi Publik berupa informasi Publik secara berkala, informasi publik yang wajib diumumkan secara serta merta, informasi yang wajib tersedia setiap saat, dan/atau informasi publik yang harus diberikan atas dasar permintaan sesuai dengan Undang-Undang ini, dan mengakibatkan kerugian bagi orang lain dikenakan pidana kurungan paling lama 1 (satu) tahun dan/atau pidana denda paling banyak Rp. 5. 000.000 (lima juta rupiah)".

Pasal 56 :

"Setiap pelanggaran yang dikenai sanksi pidana dalam Undang-Undang ini dan juga diancam dengan sanksi pidana dalam Undang-Undang lain yang bersifat khusus, yang berlaku adalah sanksi pidana dari UndangUndang yang lebih khusus tersebut."

Pasal 57 :

"Tuntutan pidana berdasarkan Undang-Undang ini merupakan delik aduan dan diajukan melalui peradilan umum".

Berdasarkan Surat Edaran Nomor: 1 Tahun 2012 Tentang Penanganan Tindak Pidana Dalam Undang-Undang Keterbukaan Informasi Publik angka 13 menyatakan bahwa:

a. Tuntutan pidana dalam tindak pidana sebagaimana dimaksud dalam pasal 52 UU Keterbukaan Informasi Publik dapat dilakukan pada saat putusan Komisi Informasi yang sudah berkekuatan hukum tetap tidak dilaksanakan.

b. Bahwa proses permohonan informasi mengalami penolakan dan/atau tidak ditanggapi maka harus diselesaikan terlebih dahulu melalui Komisi Informasi. Dengan demikian proses tuntutan pidana tanpa adanya putusan penyelesaian sengketa informasi publik oleh komisi informasi tidak dapat dilanjutkan.

c. Upaya hukum keberatan terhadap putusan komisi informasi (baik dalam hal prosedur atau substansi) hanya dapat dilakukan melalui keberatan kepada PTUN atau Pengadilan Negeri, sehingga Majelis Komisioner dalam memutus sengketa informasi tidak dapat dipanggil atau diperiksa sebagai saksi atau tersangka dalam dugaan tindak pidana UU Keterbukaan Informasi Publik.

d. Sehubungan dengan tidak adanya regulasi yang mengatur mekanisme keberatan atas penetapan Majelis Pemeriksa Pendahuluan, maka upaya hukum atas keberatan penetapan majelis pemeriksa pendahuluan adalah keberatan melalui PTUN atau Pengadilan Negeri.

Di dalam KD. 37/DIRUT/0614 tentang Penerimaan Karyawan PT. Pos Indonesia Intake Program Diploma III (DIII) untuk Kepala Kantor Pos Cabang menimbulkan Hak bagi Pemohon (Pekerja) dan Kewajiban bagi Termohon (Perusahaan PT. Pos Indonesia (Persero) Regional II Padang). Hak bagi Pemohon (Pekerja) adalah berhak atas:

a. Pemohon (Pekerja) dinyatakan lulus seleksi, dan menjadi peserta program pembelajaran.

b. Pemohon sebagai peserta program pembelajaran diangkat menjadi karyawan Perusahaan dengan Grade 13.

c. Pemohon ditempatkan sebagai Kepala Kantor Pos Cabang diberikan kelompok jabatan Penyelia II. 
Izza Hasna Fuada: Penyelesaian Sengketa Antara Pekerja Dan Perusahaan Tentang Hak...

d. Pemohon sebagai peserta program pembelajaran diberikan hak-hak sesuai dengan ketentuan yang berlaku di Perusahaan dan pelayanan kesehatan di Poliklinik Perusahaan.

e. Pemohon akan ditempatkan di kantor pos cabang wilayah kerja area.

Sedangkan kewajiban Termohon (Perusahaan PT. Pos Indonesia (Persero) Regional II Padang untuk memberikan hasil pemeriksaan kesehatan atas nama pemohon, memberikan penjelasan tertulis dari dokter serta salinan rekap hasil pemeriksaan kesehatan atas nama pemohon dalam Tes Penerimaan Karyawan PT. Pos Indonesia Intake Program Diploma III (D-III) untuk Kepala Kantor Pos Cabang. Dan Termohon berkewajiban melaksanakan Tes Penerimaan Karyawan PT. Pos Indonesia Intake Program Diploma III (DIII) untuk Kepala Kantor Pos Cabang sesuai dengan Keputusan Direksi PT. Pos Indonesia (Persero) Nomor: KD. 37/DIRUT/0614 dan Perjanjian Kerja Bersama (PKB) dengan Serikat Pekerja Pos Indonesia (SPPI) Tahun 2014 Bab III Tentang Hubungan Kerja.

3. Kendala Pekerja untuk menindak lanjuti hak yang diperoleh setelah Putusan Mediasi Komisi Informasi Pusat Nomor: 1356/KIP-PS-AM/2014 dalam KD.37/DIRUT/0614 Tentang Penerimaan Karyawan PT. Pos Indonesia (Persero) Intake Program D-III untuk calon Kepala Kantor Pos Cabang

Setelah dipenuhinya permintaan informasi oleh perusahaan PT. Pos Indonesia (Persero) Regional II Padang berdasarkan Kesepakatan Mediasi, maka terdapat Kendala Pekerja untuk menindak lanjuti hak yang terdapat di dalam KD.37/DIRUT/0614 tentang Penerimaan Karyawan PT. Pos Indonesia (Persero) Intake Program D-III untuk calon Kepala Kantor Pos Cabang, berdasarkan hasil penelitian yang diperoleh dari hasil wawancara terdapat berbagai kendala yang dihadapi oleh pekerja yaitu (wawancara dengan Pekerja yang bernama Aqtia Susepti).

a. Karena tidak adanya pengawasan dan tindak lanjut oleh Komisi Informasi Pusat terhadap putusan mediasi khusus nomor 1356/XI/KIP-PS-AM/2014 terhadap pihak-pihak yang bersengketa, karena belum adanya peraturan perundang-undangan yang mengatur mengenai putusan mediasi yang bersifat final dan mengikat khusus penyelesaian sengketa antara pekerja dengan perusahaan pada Komisi Informasi Pusat.

b. Pekerja berasumsi apabila perusahaan PT. Pos Indonesia (Persero) meluluskan pihak pekerja, maka akan ditempatkan kemungkinan di daerah yang sangat jauh dari domisili pekerja dan keluarga pekerja, karena telah terjadi sengketa.

c. Setelah dikeluarkan putusan mediasi oleh Komisi Informasi Pusat Nomor 1356/XI/KIP-PS-A-M/2014, tentunya pekerja dan perusahaan bermusyawarah kembali untuk melanjutkan keputusan direksi nomor 37/DIRUT/0614 tentang Penerimaan Karyawan PT. Pos Indonesia 
(Persero) intake program diploma III (D-III) untuk Kepala Kantor Pos Cabang karena adanya perselisihan Hak sebagaimana diatur di dalam UU RI No. 13 Tahun 2003 tentang Ketenagakerjaan dan UU RI No. 2 Tahun 2004 tentang Penyelesaian Perselisihan Hubungan Industrial yang akan membutuhkan waktu yang lama sehingga menimbulkan biaya yang besar karena posisi pekerja yang berada jauh antara Kantor Cabang dengan Kantor Pusat.

Sedangkan kendala hukumnya adalah bahwa dalam bidang ketenagakerjaan apabila terjadi Perselisihan Hubungan Industrial hanya ada aturan yaitu UndangUndang RI No. 13 Tahun 2003 tentang Ketenagakerjaan dan Undang-Undang RI No. 2 Tahun 2004 Tentang Penyelesaian Perselisihan Hubungan Industrial yang hanya mengatur 4 (Empat) jenis perselisihan yaitu perselisihan hak, perselisihan kepentingan, perselisihan pemutusan hubungan kerja (PHK) dan perselisihan antar serikat pekerja.

Di dalam perkembangan hukum yang dinamis ini perselisihan hubungan industrial tidak tentang 4 jenis perselisihan saja tetapi sudah adanya perselisihan hubungan industrial terkait dengan hak memperoleh suatu informasi, dan sampai saat ini belum adanya aturan ketenagakerjaan yang berkaitan dengan informasi.

\section{SIMPULAN}

1. Sengketa antara pekerja yang merupakan karyawan PT. Pos Indonesia (Persero) dengan Perusahaan PT. Pos Indonesia (Persero) Regional II Padang disebabkan oleh ketidaklulusan pekerja dalam Tes Penerimaan Karyawan PT. Pos Indonesia (Persero) Intake Program Diploma III (D-III) untuk Kepala Kantor Pos Cabang. Sengketa terjadi karena tidak dipenuhinya hak berupa informasi sebagaimana diatur di dalam UU RI No. 14 Tahun 2008 Tentang Keterbukaan Informasi Publik. Sengketa pekerja dan perusahaan dapat diselesaikan melalui Komisi Informasi Pusat karena hak tersebut merupakan bagian dari suatu informasi publik sebagaimana diatur di dalam UU RI No. 14 Tahun 2008 tentang Keterbukaan Informasi Publik yang dilaksanakan secara Mediasi.

2. Akibat hukum putusan Mediasi Komisi Informasi Pusat Nomor: 1356/KIP-PS-A-M/2014 dalam penyelesaian sengketa antara pekerja dan perusahaan tentang hak atas informasi hasil seleksi akhir rekrutmen karyawan PT. Pos Indonesia (Persero) Intake Program D-III untuk calon Kepala Kantor Pos Cabang Nomor: SK .2966/DIR.SDM/1014 yaitu pekerja mendapatkan haknya berupa informasi sebagaimana yang terdapat di dalam putusan mediasi komisi 
Izza Hasna Fuada: Penyelesaian Sengketa Antara Pekerja Dan Perusahaan Tentang Hak...

informasi pusat Nomor :1356/KIP-PS-

A-M-2014.

3. Kendala pekerja untuk menindak lanjuti hak yang diperoleh setelah putusan Mediasi Komisi Informasi Pusat Nomor: 1356/KIP-PS-AM/2014 dalam penerimaan karyawan PT. Pos Indonesia (Persero) Intake Program D-III untuk calon Kepala Kantor Pos Cabang yaitu Setelah dikeluarkan putusan mediasi oleh Komisi Informasi Pusat Nomor 1356/XI/KIP-PS-A-M/2014, tentunya pekerja dan perusahaan bermusyawarah kembali untuk melanjutkan keputusan direksi nomor 37/DIRUT/0614 tentang Penerimaan Karyawan PT. Pos Indonesia (Persero) intake program diploma III (D-III) untuk Kepala Kantor Pos Cabang karena adanya perselisihan hak sebagaimana diatur dalam UU No. 13 Tahun 2003 tentang Ketenagakerjaan yang akan membutuhkan waktu yang lama sehingga menimbulkan biaya yang besar karena posisi pekerja yang berada jauh antara Kantor Cabang dengan Kantor Pusat.

\section{UCAPAN TERIMA KASIH}

Terima kasih saya ucapkan kepada Bapak Dr. Sukanda Husin, SH, LLM (Dosen Universitas Andalas sebagai Pembimbing Utama), Kantor Hukum Aqtia dan Rekan (sebagai narasumber), Komisi Informasi Provinsi Sumatera Barat yang telah membantu dalam pelaksanaan penelitian dan penulisan.

\section{DAFTAR PUSTAKA}

\section{Buku}

Agus Widjayanto et.al, Buku Saku Mediasi Sengketa Informasi Publik, Komisi Informasi Pusat, Jakarta, 2015

Dyah aryani et.al, Putusan Komisi Informasi Dalam Bingkai Hukum Progresif (Putusan Komisi Informasi dari Proses Adjudikasi Nonlitigasi, Memiliki kekuatan setara dengan putusan pengadilan), Komisi Informasi Pusat RI, Jakarta Pusat, 2014

Dyah Aryani dan Yhannu Setyawan, Buku Saku Ajudikasi Nonlitigasi Sengketa Informasi Publik, Komisi Informasi Pusat, Jakarta, 2015

Evy Trislo D, Kajian Kelembagaan Komisi Informasi, Bidang Kelembagaan Komisi Informasi Pusat, Jakarta, 2015

Soemarno Partodihardjo, Tanya Jawab sekitar Undang-Undang Nomor Republik Indonesia Nomor 14 Tahun 2008 Tentang Keterbukaan Informasi Publik, PT. Gramedia Pustaka Umum, Jakarta, 2008

\section{Jurnal}

Afrizal dan Sudarman, 2017, Peningkatan

Kepatuhan Badan Publik Dalam

Pelaksanaan UU Keterbukaan

Informasi Publik Di Kabupaten Aceh Barat, Volume 3 Nomor 1, Jurnal Community

Ahmad Subhan, 2016, Penguatan Kelembagaan Komisi Informasi Daerah Dalam Mendukung Transparansi Pemerintah, Vol.21/No.3, Jurnal Kajian: 
Jurnal Cendekia Hukum: Vol. 5, No 2, Maret 2020

Menjembatani Teori dan

Persoalan Masyarakat Dalam Perumusan Kebijakan.

Angretta Lolita dan Muhammad Abudan, Kewenangan Komisi Informasi Dalam Mengadili Sengketa Informasi Publik (Studi Kasus : Forum Diskusi Suporter Indonesia Melawan Persatuan Sepak Bola Seluruh Indonesia), Jurnal Hukum Adigama

Ari Cahyo Nugroho, 2017, Komunikasi Kelompok, Diskursif, dan Public Space (Studi Kasus Fenomena Eksistensi Diskursif di lingkungan KIP daerah Provinsi Bengkulu), Vol 21 No. 2, Jurnal Studi Komunikasi dan Media

AS DW, P Harsasto, N Marlina, "Peran Komisi Informasi Provinsi Jawa Tengah dalam Mendorong Tercapainya Keterbukaan Informasi Publik di Jawa Tengah," (2016), Jurnal Of Politic and Goverment Studies 6

Fauzi Syam, 2015, Hak Atas Informasi dan Legal Standing Para Pihak Dalam Sengketa Informasi Di Komisi Informasi, Volume VIII Nomor I, Jurnal Inovatif

Krisdawati Sadhana, Etika Birokrasi Dalam Pelayanan Publik, CV. Citrab Malang, Malang, 2010, hal. 132

Muhammad Usman Noor, 2019, Inisiasi Masyarakat Informasi di Indonesia Melalui Implementasi Keterbukaan Informasi Publik: Satu Dekade UU
Keterbukaan Informasi Publik, Vol.

7 No. 1, Khizanah a-Hikmah, Jurnal Ilmu Perpustakaan, Informasi dan Kearsipan

Suhendar Ade, "Bentuk Keseriusan Pemerintah Menuju Good Governace (Implementasi UU No. 14 Tahun 2008), Jurnal Keterbukaan Informasi Publik

Renowati, Endang, "Keterbukaan Informasi Publik dan Good Governance antara Das Solen dan Das Sein" (2012), Jurnal Perspektif'

\section{Peraturan Perundang-Undangan}

Undang Undang Dasar 1945

Undang Undang Nomor 14 Tahun 2008 Tentang Keterbukaan Informasi Publik

Undang Undang Nomor 40 Tahun 2007 Tentang Perseroan Terbatas Tentang Ketenagakerjaan

Undang Undang Nomor 19 Tahun 2003 Tentang Badan Usaha Milik Negara (BUMN)

Peraturan Komisi Inforamsi Nomor 1 Tahun 2013 Tentang Prosedur Penyelesaian Sengketa Informasi Publik

Peraturan Pemerintah Republik Indonesia Nomor 61 Tahun 2010 Tentang Pelaksanaan Undang-Undang Nomor 14 Tahun 2008 Tentang Keterbukaan Informasi Publik

Peraturan Komisi Informasi Nomor 1 Tahun 2010 Tentang Standar Layanan Informasi Publik. 